\title{
Absolute quantitation of inositol pyrophosphates by capillary electrophoresis electrospray ionization mass spectrometry
}

\author{
Danye Qiu ${ }^{1}$, Verena B. Eisenbeis ${ }^{1}$, Adolfo Saiardi ${ }^{2}$, Henning J. Jessen ${ }^{1}$ \\ ${ }^{1}$ Institute of Organic Chemistry, University of Freiburg, Albertstr. 21, 79104 Freiburg, Germany. \\ ${ }^{2}$ Medical Research Council, Laboratory for Molecular Cell Biology, University College London, \\ London WC1E 6BT, UK
}

\section{SUMMARY}

We describe a procedure for capillary electrophoresis electrospray ionization mass spectrometry for the absolute quantitation of inositol pyrophosphates from mammalian cell extracts.

\begin{abstract}
Inositol pyrophosphates (PP-InsPs) are an important group of intracellular signaling molecules. Derived from inositol phosphates (InsPs), these molecules feature the presence of at least one energetic pyrophosphate moiety on the myo-inositol ring. They exist ubiquitously in eukaryotes and operate as metabolic messengers surveying phosphate homeostasis, insulin sensitivity, and cellular energy charge. Owing to the absence of a chromophore in these metabolites, a very high charge density, and low abundance, their analysis requires radioactive tracer, and thus it is convoluted and expensive. Here, the study presents a detailed protocol to perform absolute and high throughput quantitation of inositol pyrophosphates from mammalian cells by capillary electrophoresis electrospray ionization mass spectrometry (CE-ESI-MS). This method enables the sensitive profiling of all biologically relevant PP-InsPs species in mammalian cells, enabling baseline separation of regioisomers. Absolute cellular concentrations of PP-InsPs, including minor isomers, and monitoring of their temporal changes in HCT116 cells under several experimental conditions are presented.
\end{abstract}




\section{INTRODUCTION}

Since the initial discovery of myo-inositol pyrophosphates (PP-InsPs) in $1993^{1,2}$, significant progress has been made to elucidate their biosynthesis, turnover, and functions ${ }^{3}$. Inositol pyrophosphates ubiquitously occur in eukaryotic cells ${ }^{4}$ and serve as metabolic signalling molecules critically involved in e.g. phosphate homeostasis ${ }^{5,6}$, insulin sensitivity ${ }^{7}$, calcium oscillations $^{8,9}$, vesicular trafficking ${ }^{10}$, apoptosis ${ }^{11}$, DNA repair ${ }^{12}$, immune signalling ${ }^{13}$, and others. The plethora of important processes under the control of inositol pyrophosphates calls for a deeper understanding of their cellular abundance, fluctuation, and localisation.

Although Inositolphosphates (InsPs) and PP-InsPs attracted attention across disciplines, the analysis of their abundance is routinely performed using a method developed during the ' 80 s, consisting in labelling cells with tritiated inositol, resolving the extracted PP-InsPs by strong anion exchange chromatography Sax-HPLC with subsequent scintillation counting. Newer methods based on mass spectrometry still face significant challenges: inositol pyrophosphates with up to eight phosphate units harbour phosphate esters and anhydrides leading to significant negative charge and potential phosphate loss during ionisation. There are four major types of PP-InsPs found in mammals (Figure 1): 1,5-(PP) $2-\operatorname{InsP}_{4}$ (or 1,5-InsP $P_{8}$ ), 5-PP-InsP (or 5-InsP $_{7}$ ), 1-PP-InsP 5 (or 1-InsP 7 ) and 5-PP-Ins $(1,3,4,6) \mathrm{P}_{4}$ (or 5-PP-InsP $)_{4}^{3,14}$. The physiological levels of PP-InsPs are typically in the nano- to low micromolar range with 5-PP-Ins $\mathrm{P}_{5}$ as the most abundant with cellular concentrations of $0.5-5 \mu \mathrm{M}$. 1,5-(PP) $)_{2}-\mathrm{InSP}_{4}$ and 1-PP-InsP $\mathrm{P}_{5}$ are believed to be up to around 10 $\%$ of the 5-PP-InsP 5 pool and remain difficult to trace in many cells ${ }^{15}$. 5-PP-InsP 4 with a free $\mathrm{OH}$ group is even lower in abundance and usually only becomes detectable when phosphate hydrolases are inhibited with sodium fluoride $(\mathrm{NaF})^{16}$.

The high charge density of PP-InsPs makes their separation difficult, and the occurrence of PPInsP regioisomers further complicates these efforts. As a result, most experiments relied on quantitation by metabolic radioactive labeling of cells using $\left[{ }^{3} \mathrm{H}\right]$-inositol, as background from the matrix is excluded and high sensitivity is achieved ${ }^{17,18}$. However, this method is costly, timeconsuming, and does not allow to properly distinguish related PP-InsP regioisomers. Moreover, $\left[{ }^{3} \mathrm{H}\right]$-inositol labeling does not account for endogenous inositol synthesis from glucose. A polyacrylamide gel electrophoresis (PAGE)-based method is a widely applied inexpensive alternative but limited in its sensitivity ${ }^{19,20,21,22}$. Other approaches avoiding radiolabeling have been published, including ion chromatography followed by post-column derivatization UVdetection ${ }^{23}$, hydrophilic interaction chromatography (HILIC) ${ }^{24}$, or weak anion exchange (WAX) coupled with mass spectrometry $(\mathrm{MS})^{25}$. However, they are not (yet) on par with the classic $\left[{ }^{3} \mathrm{H}\right]-$ inositol SAX-HPLC protocol.

Recently, capillary electrophoresis electrospray ionization mass spectrometry (CE-ESI-MS) was introduced as a transformative strategy for the analysis of InsPs and PP-InsPs metabolism, meeting all requirements discussed above ${ }^{16}$. Combined with current state-of-the-art InsP extraction by perchloric acid followed by enrichment with titanium dioxide beads ${ }^{26}$, CE-ESI-MS succeeded in every organism tested so far, from yeast to plants and mammals. Simultaneous profiling of InsPs and PP-InsPs, including all possible regioisomers, was easily achieved. Stable isotope-labeled (SIL) internal standards enabled a rapid and precise absolute quantitation, irrespective of matrix 
effects. Because MS can capture isotopic mass differences, CE-ESI-MS can also be applied to study compartmentalized cellular synthesis pathways of InsPs and PP-InsPs, e.g., by feeding cells with $\left[{ }^{13} \mathrm{C}_{6}\right]$-myo-inositol or $\left[{ }^{13} \mathrm{C}_{6}\right]$-D-glucose.

Described here is a detailed step-by-step protocol for the absolute quantitation of PP-InsPs and InsPs from mammalian cells by CE-ESI-MS. Apart from the major 5-PP-Ins $\mathrm{P}_{5}$ isomer, 1,5-(PP) $2_{2}$ $\mathrm{InsP}_{4}$ and 1-PP-InsP 5 are also quantified in this study, despite their lower abundance. Two HCT116 cell lines from different laboratories (NIH, UCL) are studied, and it is validated that HCT116 ${ }^{\mathrm{UCL}}$ cells contain 7-fold higher levels of 1,5-(PP) $)_{2}-\mathrm{InsP}_{4}$ than found in $\mathrm{HCT} 116^{\mathrm{NIH}}$, while 5-PP-InsP concentrations are comparable. In addition, 1-PP-InsP5 synthesis in HCT116 ${ }^{\mathrm{UCL}}$ is not significantly increased. Also, the increase of PP-InsP levels by blocking their dephosphorylation using sodium fluoride is studied quantitatively.

\section{PROTOCOL}

1. Setting up the CE-ESI-MS system

1.1 Set up a CE-ESI-MS system consisting of a commercial CE system (e.g. Agilent 7100) and a triple quadrupole tandem mass spectrometer (e.g. Agilent QQQ 6495c), equipped with an Agilent Jet Stream (AJS) electrospray ionization (ESI) source. A CE-ESI-MS sprayer kit and an isocratic LC pump (e.g. Agilent 1200) are requisite.

1.2 Connect the sheath flow 1:100 splitter (included in the Agilent CE-MS sprayer kit) and the isocratic LC pump outlet.

1.3 Make sure that the CE system inlet vial is at the same height to the sprayer tip of mass analyzer.

1.4 Utilize Agilent MassHunter Workstation (Version 10.1) or comparable MS software to control the entire system, and for data acquisition and analysis.

2. Preparing buffer, capillary and CE-MS system

2.1 Prepare CE running buffer: $40 \mathrm{mM}$ ammonium acetate adjusted to $\mathrm{pH} 9.0$ with ammonium hydroxide. A $250 \mathrm{~mL}$ volumetric flask is recommended. Filter the $250 \mathrm{~mL}$ buffer with $0.2 \mu \mathrm{m}$ pore-sized membrane filters. This buffer can be kept at room temperature for 2-3 weeks or alternatively several months in a fridge. Ultra-pure deionized water and MS grade reagents are essential.

2.2 Prepare sheath liquid: Mix $100 \mathrm{~mL}$ ultra-pure water and $100 \mathrm{~mL}$ LC-MS grade iso-propanol in a $250 \mathrm{~mL}$ bottle. Change the sheath liquid at least once a week. Add mass reference into the sheath liquid when employing a high-resolution mass spectrometer.

2.3 Install sheath liquid: Purge at $5 \mathrm{~mL} / \mathrm{min}$ for 5 mins and set flow rate at $1 \mathrm{~mL} / \mathrm{min}$ (10 $\mu \mathrm{L} / \mathrm{min}$ into the CE-MS sprayer). The pump pressure will be at ca 180 bar. Make sure that the recycle tubing connects back into the sheath liquid bottle to reuse the solvent.

2.4 Prepare capillary: CE-MS capillary $(50 \mu \mathrm{m}$ i.d. $365 \mu \mathrm{M}$ o.d. with a length of $125 \mathrm{~cm})$ with 
UV detection window can be purchased. Much cheaper bar fused silica capillaries can be also be obtained from specialized distributors, for example, CS-Chromatographie Service $\mathrm{GmbH}$ (Germany). Cut a capillary with a length of $100 \mathrm{~cm}$. Properly cut both capillary ends with a capillary column cutter with a rotating diamond blade and remove $2-3 \mathrm{~cm}$ polyimide coating on both ends with a lighter. Clean the capillary surface with isopropanol.

2.5 Install capillary: Match the capillary into the CE-MS cassette. Click on the Change Cassette button and install the cassette into the CE device. The inlet end of the capillary is around $2 \mathrm{~mm}$ lower than the electrode. Ensure that the inlet end is lower than the sample's surface during the injection process.

2.6 Activate capillary: Prior to first use, flush the capillary with $1 \mathrm{M} \mathrm{NaOH}$, followed by water for $10 \mathrm{~min}$, and CE running buffer for $15 \mathrm{~min}$.

2.7 Insert the capillary end into the CE-MS sprayer: Gently put the capillary into the CE-MS sprayer and ensure that the capillary end protrudes approximately $0.1 \mathrm{~mm}$ out of the sprayer tip. The precise adjustment of the capillary outlet end must be done with a magnifying glass and the adjustment screw in the sprayer. Insert the sprayer back into the ion source, and avoid touching the adjustment screw. The MS should be on Standby mode when performing this operation.

2.8 Check ESI spray: Check the stability of ESI sprayer under full scan mode. The fluctuation of total ion electropherograms should be within $5 \%$.

2.9 Perform a test run with InsP standards: A mixture of $2 \mu \mathrm{M}$ InsP 3 -InsP 8 standards (adjusted by quantitative ${ }^{31} \mathrm{P} N \mathrm{NM}^{15,27}$ ) are employed for test runs with an injection at 50 mbar for $10 \mathrm{~s}(10 \mathrm{~nL})$. Detailed ESI and MS parameters are set as shown in Table 1. CE current is ca $26 \mu \mathrm{A}$. Peak width is around $0.5 \mathrm{~min}$. Ensure that the signal-to-noise ratio reaches at least 400.

2.10

3. Extraction of soluble inositol phosphates from mammalian cells HCT116 ${ }^{\mathrm{NIH}}$ were a kind gift from Stephen Shears ${ }^{28}$. HCT116 ${ }^{\mathrm{UCL}}$ are from Saiardi's Lab ${ }^{26}$.

3.1 Seeding cells

3.1.1 Culture HCT116 ${ }^{\mathrm{NIH}}$ or HCT116 ${ }^{\mathrm{UCL}}$ cells in $\mathrm{T} 75$ flasks at $37^{\circ} \mathrm{C}$ in a $5 \%$ high humidity $\mathrm{CO}_{2}$ atmosphere (further referred to as standard conditions) in Dulbecco's modified eagle medium (DMEM) supplemented with $10 \%$ fetal bovine serum (FBS).

3.1.2 Wash HCT116 $6^{\mathrm{NIH}}$ and $\mathrm{HCT} 116^{\mathrm{UCL}}$ stock cultures with phosphate buffered saline (PBS) $(5 \mathrm{~mL})$ and incubate the cells with trypsin-ethylenediamine tetraacetic acid (EDTA) ( $3 \mathrm{~mL}, 0.25 \%$ ) under standard conditions until they are completely detached. Quench trypsin activity by adding medium and collect the cells into a centrifuge tube and centrifuge (200 g, $3 \mathrm{~min})$. 
3.1.3 Remove the supernatant and resuspend the cells in medium (10 mL). Count the cells and determine the viability via trypan blue exclusion.

3.1.4 Seed the cells ( 6 million HCT116 cells per assay) into a $150 \mathrm{~mm}$ dish and adjust $20 \mathrm{~mL}$ of cell culture medium in total. Premix the medium and the cells in a centrifuge tube prior to seeding in order to achieve an equal distribution of the cells in the dish. Prepare a parallel dish when normalization by cell number is required.

3.1.5 Culture the cells under standard conditions for $72 \mathrm{~h}$. The cells will reach about $80-90 \%$ confluence.

3.2 Modulation of inositol phosphate levels with $\mathrm{NaF}$ and cell harvesting

3.2.1 NaF treatment: Add NaF $(10 \mathrm{mM}) 1 \mathrm{~h}$ before harvest into the medium. Mix the medium by swirling the plate/pipetting and incubate the cells for 60 min under standard conditions.

3.2.2 After NaF treatment, remove the medium from the cells and place the cells on ice.

3.2.3 Wash the cells twice with PBS $\left(5 \mathrm{~mL}, 4^{\circ} \mathrm{C}\right)$ and remove the PBS completely from the dish.

3.2.4 Add perchloric acid (PA) $\left(1 \mathrm{~mL}, 1 \mathrm{M}, 4^{\circ} \mathrm{C}\right)$. Ensure that the whole surface is covered with PA (the cells will turn white as proteins precipitate). Incubate the cells for 10 min on a tilt table at $4{ }^{\circ} \mathrm{C}$.

3.2.5 Collect PA into a centrifuge tube and remove contaminating debris by centrifugation $\left(17.000 \mathrm{~g}, 5 \mathrm{~min}, 4^{\circ} \mathrm{C}\right.$ ). Add the supernatant to the prepared $\mathrm{TiO}_{2}$ beads for the pulldown of InsPs.

3.2.6 Wash the post-extraction dish twice with PBS (5 mL, r.t.) for deacidification; remove PBS completely from the dish.

3.2.7 Solubilize proteins on the plate via addition of cell lysis buffer ( $1.5 \mathrm{~mL}$, r.t.; $0.1 \%$ sodium dodecyl sulfate [SDS] in $0.1 \mathrm{M} \mathrm{NaOH}$ ). Incubate the dish for 15 min on a tilt table at r.t. Transfer the cell lysate into a centrifuge tube and centrifuge (17.000 g, $5 \mathrm{~min}, 4^{\circ} \mathrm{C}$ ). Store the supernatant at $-80^{\circ} \mathrm{C}$ until the protein concentration is determined via the DC protein assay using bovine serum albumin as calibration standard (usually, one $150 \mathrm{~mm}$ dish contains around $10 \mathrm{mg}$ of proteins).

3.2.8 Determination of cell numbers from parallel dishes: Harvest the cells of the parallel dish via trypsin as described in section 3.1.2 (use $5 \mathrm{~mL}$ trypsin-EDTA for the $150 \mathrm{~mm}$ dish) and remove the medium. Resuspend the cell pellet in PBS (5 $\mathrm{mL}$ ), mix properly, and count the cells. Perform this step right before harvest via direct quenching to obtain representative cell counts. Additionally, measure the volume of the cells with an appropriate method (e. g. with a multisizer machine). 


\section{3 $\mathrm{TiO}_{2}$ enrichment of inositol phosphates}

To avoid acidic decomposition of phosphorylated compounds, all steps of the enrichment until elution need to be performed on ice and all reagents need to be cooled to $4{ }^{\circ} \mathrm{C}$. The time for the extraction should be kept to a minimum (1.5-2 h). All of the extraction steps are performed with $1 \mathrm{M}$ PA.

3.3.1 Preparation of beads: Wash $\mathrm{TiO}_{2}$ beads ( $5 \mathrm{mg}$ per sample) with $\mathrm{dd}_{2} \mathrm{O}(1 \mathrm{~mL})$ and centrifuge $\left(3.500 \mathrm{~g}, 1 \mathrm{~min}, 4^{\circ} \mathrm{C}\right)$. Remove $\mathrm{ddH}_{2} \mathrm{O}$ and wash the beads with PA $(1 \mathrm{~mL})$. Remove PA by centrifugation $\left(3.500 \mathrm{~g}, 1 \mathrm{~min}, 4^{\circ} \mathrm{C}\right)$. Resuspend the beads in PA (50 $\mu \mathrm{L}$ per sample).

3.3.2 Add the supernatant containing phosphorylated compounds (compare section 3.2, step 3.2.6) to the bead suspension, vortex and then rotate the sample for $20 \min$ at $4{ }^{\circ} \mathrm{C}$

3.3.3 Centrifuge the sample $\left(3.500 \mathrm{~g}, 1 \mathrm{~min}, 4^{\circ} \mathrm{C}\right.$ ) and discard the supernatant. Wash the beads with PA $(500 \mu \mathrm{L})$ and centrifuge $\left(3.500 \mathrm{~g}, 1 \mathrm{~min}, 4^{\circ} \mathrm{C}\right)$. Discard the supernatant and repeat the washing step.

3.3.4 Add $\mathrm{NH}_{4} \mathrm{OH}(200 \mu \mathrm{L}, 3 \%)$ to the beads and resuspend. Rotate the sample for $5 \mathrm{~min}$ at r.t.

3.3.5 Centrifuge the sample $(3500 \mathrm{~g}, 1 \mathrm{~min})$ and transfer the supernatant into a new centrifuge tube.

3.3.6 Repeat elution steps 3.3.4 and 3.3.5 and combine the eluents. The beads can be discarded.

3.3.7 Centrifuge the combined eluents $\left(17.000 \mathrm{~g}, 1 \mathrm{~min}, 4^{\circ} \mathrm{C}\right)$ to remove any insoluble residues.

3.3.8 Completely dry the supernatant under vacuum evaporation ( $70 \mathrm{~min}, 60^{\circ} \mathrm{C}, \mathrm{V}-\mathrm{AQ}$ ). Add $\mathrm{dd}_{2} \mathrm{O}(50 \mu \mathrm{L})$ to the dried extracts containing InsPs. Vortex mix the sample until completely dissolved. Store the sample at $-20^{\circ} \mathrm{C}$ until CE-ESI-MS analysis.

4. Performing the CE-ESI-MS runs

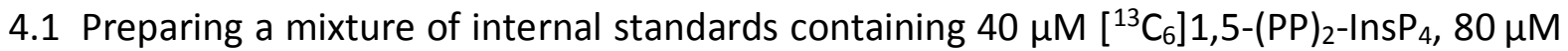
$\left[{ }^{13} \mathrm{C}_{6}\right] 5-\mathrm{PP}-$ InsP,$\quad 80 \mu \mathrm{M} \quad\left[{ }^{13} \mathrm{C}_{6}\right]$ 1-PP-InsP,$\quad 400 \mu \mathrm{M} \quad\left[{ }^{13} \mathrm{C}_{6}\right] \mathrm{InsP}_{6} \quad$ and $\quad 400 \mu \mathrm{M}$ $\left[{ }^{13} \mathrm{C}_{6}\right] \operatorname{Ins}(1,3,4,5,6) \mathrm{P}_{5}$. All above SIL internal standards (IS) with purities higher than $96 \%$ were synthesized and provided by Fiedler group ${ }^{15,27}$. Concentrations of SIL IS solutions were determined by quantitative ${ }^{31} \mathrm{P}$ and ${ }^{1} \mathrm{H}$ NMR against a certified reference standard (phosphoacetic acid).

4.2 Mix $10 \mu \mathrm{L}$ sample with $0.5 \mu \mathrm{L}$ internal standards mixture in CE sample vial. $2 \mu \mathrm{M}\left[{ }^{13} \mathrm{C}_{6}\right] 1,5-$ $(\mathrm{PP})_{2}$-InsP $4,4 \mu \mathrm{M}\left[{ }^{13} \mathrm{C}_{6}\right] 5$-PP-InsP, $4 \mu \mathrm{M}\left[{ }^{13} \mathrm{C}_{6}\right]$ 1-PP-InsP $\mathrm{P}_{5}, 20 \mu \mathrm{M}\left[{ }^{13} \mathrm{C}_{6}\right]$ InsP 6 and $20 \mu \mathrm{M}$ $\left[{ }^{13} \mathrm{C}_{6}\right] \operatorname{lns}(1,3,4,5,6) \mathrm{P}_{5}$ are the final concentrations inside samples. 
4.3 When using replenishment system, put the prepared $250 \mathrm{~mL}$ CE running buffer into the electrolyte bottle, click clean tubes. Keep the replenishment needle in a water vial.

4.4 Set ESI and MS parameters as shown in Table 1.

4.5 Perform a run for the InsP extracts and check the result (Figure 2). Run a sequence when there are more samples.

4.6 Standby the MS after measurements. Do not turn off the LC pump. The flow of sheath liquid protects the sprayer needle.

5. Data analysis

5.1 Open Agilent MassHunter Quantitative Analysis (for QQQ), create a batch for all samples.

5.2 Create new Method from acquired MRM data. Set the internal standards as ISTD. Check MRM compound setup, retention time setup, ISTD setup, concentration setup and qualifier setup. Pass the validation and exit to apply the method to current batch.

5.3 Check if each peak in the batch are properly integrated, otherwise manually integrate the peak.

5.4 Export the results into a excel file. Quantitation of inositol (pyro)phosphates are performed by comparing analyte peak response with the respective peak response of SIL IS with known concentrations.

5.5 With the measured concentration in the InsP extract solution and its volume, absolute amounts can be calculated. Further normalize the amount by cell counts or protein content. Cellular concentration is calculated based on cell counts and average cell volume of HCT116 (1.68 fL).

\section{REPRESENTATIVE RESULTS}

The results shown here aim to illustrate the potential of CE-ESI-MS analysis. The reported figures are descriptive of technically flawless CE-ESI-MS run. Firstly, a mixture of inositol pyrophosphate standards (Figure 1) and a mammalian cell extract (Figure 2) are presented. Secondly, a comparison of two HCT116 cell lines (Figure 3) and NaF-treated HCT116 (Figure 4) cells are provided.

Extracted ion electropherograms (EIEs) of inositol (pyro)phosphate standards at a concentration of $2 \mu \mathrm{M}$ are shown in Figure 1. Metabolism of inositol pyrophosphates in mammals with their simplified structures is inserted. The four inositol pyrophosphates in mammals, $1,5-(\mathrm{PP})_{2}-\mathrm{InsP}_{4}$, 5-PP-Ins $\mathrm{P}_{5}, 1-\mathrm{PP}-\mathrm{Ins} \mathrm{P}_{5}$ and 5-PP-Ins $(1,3,4,6) \mathrm{P}_{4}$ are well distinguished using the described method.

A CE-ESI-MS run of HCT116 ${ }^{\mathrm{UCL}}$ is depicted in Figure 2. With the aid of stable isotope labeled (SIL) internal standards, an absolute quantitation can be readily achieved by comparing the signal response with the spiked-in SIL of known concentration. The integrated EIEs of the inositol 
phosphate from InsP $_{5}$ - to $(\mathrm{PP})_{2}$ - $\mathrm{InsP}_{4}$ ) and un-integrated EIEs of their isotopic patterns are displayed. RSDs of all analytes from six technical repeats are within $4 \%$. With the measured concentration and the volume of extracts, the amount of analytes can be calculated. With the cell counts and cell volume, or protein content, absolute cellular concentration $(\mu \mathrm{M})$ or amount normalized by protein content (pmol/mg protein) are commonly the final outcomes of such an analysis.

According to an earlier study, two batches of diverged HCT116 cells have variation of InsP 8 levels, HCT116 ${ }^{\mathrm{UCL}}$ cells contain 6 -fold higher levels of $\mathrm{InsP}_{8}$ than $\mathrm{HCT} 116^{\mathrm{NIH}}$ cells ${ }^{29}$. With the CE-MS method, $1,5-(\mathrm{PP})_{2}-\mathrm{InsP}_{4}$ in $\mathrm{HCT} 116^{\mathrm{NIH}}$ could be easily quantified (Figure 3 ), and $\mathrm{HCT} 116^{\mathrm{UCL}}$ cells contain 7-fold higher levels of InsP 8 than in $\mathrm{HCT} 116^{\mathrm{NIH}}$. In addition, the higher accumulation of 1,5-(PP) ${ }_{2}-\mathrm{InsP}_{4}$ in HCT116 ${ }^{\mathrm{UCL}}$ cells is not accompanied by a significantly increased 1-PP-InsP 5 synthesis, which is now quantitatively shown in Figure 3.

Levels of PP-InsPs increase by blocking their dephosphorylation using sodium fluoride. CE-ESI-MS analysis of NaF-treated $\mathrm{HCT} 116^{\mathrm{NIH}}$ demonstrated the expected 5-PP-InsP $\mathrm{P}_{5}$ elevation with concomitant reduction in $\operatorname{lns} \mathrm{P}_{6}$ and an appearance of 5 -PP-Ins $(1,3,4,6) \mathrm{P}_{4}$ (Figure 4). Besides, the elevation of $\mathrm{InsP}_{8}$ levels is noticeable, while 1-PP-InsP $\mathrm{P}_{5}$ decreases to some degree. 1-PP-InsP $\mathrm{P}_{5}$ is not completely absent in NaF-treated $\mathrm{HCT} 116^{\mathrm{NIH}}$, but mostly either under limit of detection or quantitation.

\section{FIGURE AND TABLE LEGENDS}

Figure 1: Typical extracted ion electropherograms (EIEs) of inositol (pyro)phosphate standards in CE-ESI-MS analysis using the described protocol. Concentration of each analyte is $2 \mu \mathrm{M}$. Injected sample volume is ca $10 \mathrm{~nL}$ with an injection at $50 \mathrm{mbar}$ for $10 \mathrm{~s}$. Inserts show metabolism of inositol pyrophosphates in mammals. IPPK: inositol pentakisphosphate 2-kinase, IP6K: inositol hexakisphosphate kinase, PPIP5K: diphosphoinositol pentakisphosphate kinase, DIPP1: diphosphoinositolpolyphosphate phosphohydrolase 1.

Figure 2: Representative InsP profile of $\mathrm{HCT} 116^{\mathrm{UCL}}$ cells. (A) EIEs of the main inositol (pyro)phosphates in HCT116 ${ }^{\mathrm{NIH}}$ and spiked SIL ISs $2 \mu \mathrm{M}\left[{ }^{13} \mathrm{C}_{6}\right] 1,5-(\mathrm{PP}){ }_{2}-\mathrm{InsP}_{4}(\mathbf{1}), 4 \mu \mathrm{M}\left[{ }^{13} \mathrm{C}_{6}\right] 5-\mathrm{PP}$ InsP $P_{5}$ (2), $4 \mu \mathrm{M}\left[{ }^{13} \mathrm{C}_{6}\right]$ 1-PP-InsP $\mathrm{P}_{5}(3), 20 \mu \mathrm{M}\left[{ }^{13} \mathrm{C}_{6}\right] \operatorname{lns} \mathrm{P}_{6}$ (4) and $20 \mu \mathrm{M}\left[{ }^{13} \mathrm{C}_{6}\right] \operatorname{Ins}(1,3,4,5,6) \mathrm{P}_{5}(5)$. Inserts show six technical repeats of InsP analysis by CE-ESI-MS, data are presented as means \pm SD. (B) Cellular concentration of PP-InsPs and InsPs in human cell lines HCT116 ${ }^{\mathrm{UCL}}$ and (C) PP-InsPs and InsPs amount normalized by protein content. Data are means \pm SEM from three independent experiments.

Figure 3: Variation in Ins $\mathrm{P}_{\mathbf{8}}$ levels between two diverged HCT116 cells. (A) EIEs of inositol pyrophosphate in $\mathrm{HCT} 116^{\mathrm{UCL}}$ and $\mathrm{HCT} 116^{\mathrm{NIH}}$. InsP 8 in $\mathrm{HCT} 116^{\mathrm{UCL}}$ is markedly more abundant than in $\mathrm{HCT} 116^{\mathrm{NIH}}$. (B) Ratio of inositol pyrophosphate to InsP 6 (\%) in both HCT116 cells. HCT116 $\mathrm{UCL}$ cells contain 7-fold higher levels of $\mathrm{InSP}_{8}$ as compared to in $\mathrm{HCT}_{116}{ }^{\mathrm{NIH}}$, while the 5-PP-InsP $\mathrm{P}_{5}$ levels are equal. Data are means \pm SEM from three independent experiments. 
Figure 4: Inositol (pyro)phosphate levels in HCT116 ${ }^{\mathrm{NIH}}$ cells, with NaF treatment. (A) EIEs of inositol (pyro)phosphate in HCT116 ${ }^{\mathrm{NIH}}$ with sodium fluoride treatment ( $\left.\mathrm{NaF}, 10 \mathrm{mM}\right)$. Levels of inositol pyrophosphate including 1,5-(PP) - InsP $_{4}, 5-P P-I n s P_{5}$ and 5-PP-Ins $(1,3,4,6) \mathrm{P}_{4}$ increase via blocking their dephosphorylation using NaF. (B)Inositol (pyro)phosphate levels (amounts are normalized by protein content) in untreated and NaF-treated HCT116 ${ }^{\mathrm{NIH}}$ cells. Data are means \pm SEM from three independent experiments.

Table 1: CE-ESI-MS parameter settings. Source parameter and iFunnel parameters are optimized by Source and iFunnel Optimizer. MSM parameter setting for inositol (pyro)phosphates are optimized by MassHunter Optimizer.

\section{DISCUSSION}

Here we present a practical and sensitive method for the quantitation of highly charged inositol pyrophosphates in mammalian cells. Combining this analysis approach with current state-of-theart InsP extraction with perchloric acid followed by enrichment with $\mathrm{TiO}_{2}, \mathrm{CE}-\mathrm{ESI}-\mathrm{MS}$ analysis has unprecedented advantages. With regards to its throughput, sensitivity, stability, absolute quantitation, isomer identification and matrix in-dependence, this method stands out compared to other approaches. Here we only describe the protocol for mammalian cells, but indeed this strategy succeeds in many different samples (e.g. yeast, plants, parasites, mouse tissues etc.).

In our laboratory, the CE-ESI-MS device runs smoothly and can accommodate around 200 samples every week. Unlike HPLC though, CE has been regarded a method for experts and specialized persons for a long time, which restricted its market and limited its application. Thus, a CE-ESI-MS device is usually absent in analytical faculties. People who wants to carry out CE-ESIMS analysis probably lack CE experience and will spend more time on trouble shooting. Here, we therefore emphasize the critical steps. First and foremost is the quality of the capillary cut. Sensitivity and stability of ESI spray mostly rely on a first-class capillary cut. Secondly, the capillary outlet end should be exactly $0.1 \mathrm{~mm}$ out of the sprayer tip. Sprayer needle and the CE capillary should be in axial direction. The quality of the ESI spray is critical for quantitation, technical runs should be performed to evaluate the repeatability.

With the described protocol, limit of quantitation (LOQ) for PP-InsPs is $40 \mathrm{nM}$ with an injection at 50 mbar for $10 \mathrm{~s}(10 \mathrm{~nL})$. There are several approaches to further increase the method sensitivity. Firstly, an injection at 100 mbar for 20 s (40 nL) will still result in a good peak shape and sufficient resolution for regioisomers 5-PP-InsP 5 and 1-PP-InsP $P_{5}$. Secondly, InsP extracts can be dissolved in a smaller amount of water. Thirdly, the dwell time could be increased when using less MRM transitions for quantitation.

The $\mathrm{CE}$ running buffer with $\mathrm{pH} 9$ provides the best resolution between $\operatorname{InsP}_{6}$-Ins $\mathrm{P}_{8}$. When increasing $\mathrm{pH}$ to 9.7 , the resolution among $\operatorname{InsP}_{3}-\mathrm{InsP}_{6}$ will significantly improve. Due to the excellent resolution, a shorter capillary length of $60 \mathrm{~cm}$ is recommended for further increasing the throughput. According to different research demands, modifications of this method can 
further facilitate InsPs and PP-InsPs analysis. Therefore, the described CE-ESI-MS protocols has the potential of opening novel research avenues into this multifaceted family of signaling molecules.

\section{ACKNOWLEDGMENTS}

This project has received funding from the European Research Council (ERC) under the European Union's Horizon 2020 research and innovation program (grant agreement no. 864246, to H.J.J.). D.Q. acknowledges financial support from the Brigitte-Schlieben-Lange-Programm. AS is supported by the MRC programme grant MR/T028904/1.

\section{DISCLOSURES}

The authors declare no competing interests.

\section{METERIALS}

\begin{tabular}{|c|c|c|c|}
\hline Name & Company & Catalog Number & Comments \\
\hline \multicolumn{4}{|l|}{ Materials } \\
\hline $\begin{array}{l}1.5 \mathrm{~mL} \text { microcentrifuge } \\
\text { tubes }\end{array}$ & Greiner Bio-One & 616201 & - \\
\hline $\begin{array}{l}15 \mathrm{~cm} \text { tissue culture } \\
\text { dishes }\end{array}$ & Thermo Fisher & 168381 & - \\
\hline $\begin{array}{l}2.0 \mathrm{~mL} \text { microcentrifuge } \\
\text { tubes }\end{array}$ & Greiner Bio-One & 623201 & - \\
\hline $50 \mathrm{~mL}$ centrifuge tubes & Greiner Bio-One & 227261 & - \\
\hline 96-well plates & Thermo Fisher & 260836 & for the DC protein assay \\
\hline CE fused silica capillary & $\begin{array}{l}\text { CS } \\
\text { Chromatographie }\end{array}$ & 105180 & $50 \mu \mathrm{M}$ i.d. $360 \mu \mathrm{M}$ o.d. \\
\hline Pipette tips & Starlab & $\begin{array}{l}\text { I1054-0001, S1111- } \\
6701, \quad \text { S1113-1700, } \\
\text { S1111-3700 }\end{array}$ & $\begin{array}{l}10 \mathrm{~mL}, 1000 \mu \mathrm{L}, 200 \mu \mathrm{L}, 10 \\
\mu \mathrm{L} \text { pipette tips }\end{array}$ \\
\hline Serological pipets & TPP & $\begin{array}{l}94550,94525,94010, \\
94005\end{array}$ & $\begin{array}{l}50 \mathrm{~mL}, 25, \mathrm{~mL}, 10 \mathrm{~mL}, 5 \mathrm{~mL} \\
\text { serological pipettes }\end{array}$ \\
\hline T75 flasks & TPP & 90076 & - \\
\hline $\begin{array}{l}\text { Chemicals } \\
\text { Reagents }\end{array}$ & & & \\
\hline
\end{tabular}

$\mathrm{NaOH}$

AppliChem

A6829,0500

sodium hydroxide pellets for molecular biology, for 


\begin{tabular}{|c|c|c|c|}
\hline $0.25 \%$ trypsin-EDTA & Gibco & 25200056 & - \\
\hline Ammonium acetate & Thermo Fisher & 1677373 & HPLC grade \\
\hline BSA & Thermo Fisher & 23209 & $\begin{array}{l}\text { albumin standard }(2.0 \\
\mathrm{mg} / \mathrm{mL}) \text { for standard curve } \\
\text { preparation }\end{array}$ \\
\hline DC protein assay & Biorad & 5000116 & $\begin{array}{l}\text { DC protein assay reagents } \\
\text { package }\end{array}$ \\
\hline DMEM & Gibco & 41966029 & high glucose, pyruvate \\
\hline FBS & Gibco & $\begin{array}{l}\text { 10270106, } 10500064 \\
\text { (heat inactivated) }\end{array}$ & $\begin{array}{l}10270106 \text { for HCT116 } \\
10500064 \text { for } \mathrm{HCT} 116^{\mathrm{NIH}}\end{array}$ \\
\hline Isopropanol & Carl Roth & AE73.2 & 99.95\% LC-MS grade \\
\hline $\mathrm{NH}_{4} \mathrm{OH}, 10 \%$ & Carl Roth & 6756.1 & $\begin{array}{l}\text { for preparation of } 3 \% \\
\mathrm{NH}_{4} \mathrm{OH}\end{array}$ \\
\hline PBS & Gibco & 10010015 & - \\
\hline Perchloric acid, 70\% & Carl Roth & 9216.1 & $\begin{array}{l}\text { for preparation of } 1 \mathrm{M} \\
\text { perchloric acid }\end{array}$ \\
\hline SDS & SERVA & 20760.02 & $\begin{array}{l}\text { for preparation of cell lysis } \\
\text { buffer }\end{array}$ \\
\hline Sodium fluoride & Sigma Aldrich & S7920 & - \\
\hline $\mathrm{TiO}_{2}$ beads & GL Sciences & $5020-75000$ & $5 \mu \mathrm{m}$ particle size \\
\hline Trypan blue solution & Gibco & 15250061 & trypan blue stain (0.4\%) \\
\hline $\begin{array}{l}\text { Ultrapure (Type 1) } \\
\text { water }\end{array}$ & Milli-Q & ZRQSVP3WW & $\begin{array}{l}\text { model: Direct-Q } 3 \text { UV Water } \\
\text { Purification System }\end{array}$ \\
\hline \multicolumn{4}{|l|}{ Equipment } \\
\hline Analytical balance & Mettler Toledo & 30105893 & $\begin{array}{l}\text { model: XPE26; for weighing } \\
\text { of beads ( } 5-6 \text { mg per sample) }\end{array}$ \\
\hline Automated cell counter & Logos Biosystems & L40002 & $\begin{array}{l}\text { model: LUNA-II Automated } \\
\text { Cell Counter }\end{array}$ \\
\hline Benchtop centrifuge & Hettich & 1401 & model: UNIVERSAL 320 \\
\hline $\begin{array}{l}\text { Benchtop centrifuge } \\
\text { with cooling }\end{array}$ & VWR & $521-1647 P$ & model: Microstar 17R \\
\hline CE system & Agilent & G7100A & - \\
\hline CE/MS Adapter Kit & Agilent & G1603A & - \\
\hline CE/MS Sprayer Kit & Agilent & G1607A & - \\
\hline Cell counting slides & Logos Biosystems & L12001 & LUNA Cell Counting Slides \\
\hline Centrifugal evaporator & Eppendorf & 5305000304 & model: Concentrator plus \\
\hline
\end{tabular}




\begin{tabular}{|c|c|c|c|}
\hline & & & complete system \\
\hline ESI source & Agilent & AJS ESI & - \\
\hline Super Support Film & $\begin{array}{l}\text { Nisshin EM Co. Ltd, } \\
\text { Tokyo }\end{array}$ & \multicolumn{2}{|l|}{647} \\
\hline Humidified incubator & Binder & $9040-0088$ & $\begin{array}{l}\text { model: CB E6.1, for } \\
\text { cultivation of mammalian } \\
\text { cells }\end{array}$ \\
\hline Ice box & - & - & $\begin{array}{l}\text { should provide enough } \\
\text { space for samples, dishes, } \\
\text { etc. }\end{array}$ \\
\hline Isocratic LC system & Agilent & $\begin{array}{l}\text { G7110B } 1260 \\
\text { Pump }\end{array}$ & $\begin{array}{l}\text { Iso model: Infinity II Quaternary } \\
\text { system }\end{array}$ \\
\hline MSD & Agilent & G6495C & triple quadrupole \\
\hline Multiplate reader & Tecan & 30086375 & model: SPARK $10 \mathrm{M}$ \\
\hline Pipette filler & Thermo Fisher & 10072332 & for serological pipettes \\
\hline Pipettes & Brand & $\begin{array}{l}705884 \\
705878 \\
705870\end{array}$ & 705872 , various pipettes \\
\hline Rotator & Labnet & H5500 & $\begin{array}{l}\text { model: Mini LabRoller } \\
\text { Rotator }\end{array}$ \\
\hline $\begin{array}{l}\text { Shortix capillary } \\
\text { column cutter }\end{array}$ & SGT & S0020 & - \\
\hline $\begin{array}{l}\text { Test tube shaker } \\
\text { (vortex mixer) }\end{array}$ & Carl Roth & HXH6.1 & model: Rotilabo-Mini Vortex \\
\hline Tilt table & Labnet & S0600 & $\begin{array}{l}\text { model: EDURO MiniMix } \\
\text { Nutating Mixer }\end{array}$ \\
\hline Water bath & Thermo Fisher & \multirow[t]{2}{*}{ FSGPD05 } & model: Isotemp GPD 05 \\
\hline \multicolumn{3}{|l|}{ Software } & \\
\hline $\begin{array}{l}\text { MassHunter } \\
\text { Workstation }\end{array}$ & Agilent & Version 10.1 & - \\
\hline $\begin{array}{l}\text { MassHunter } \\
\text { Workstation LC/MS } \\
\text { Data Acquisition }\end{array}$ & Agilent & Version 10.1 & - \\
\hline $\begin{array}{l}\text { MassHunter } \\
\text { Workstation Optimizer }\end{array}$ & Agilent & Version 10.1 & - \\
\hline $\begin{array}{l}\text { MassHunter } \\
\text { Workstation } \\
\text { Qualitative Analysis }\end{array}$ & Agilent & Version 10.0 & - \\
\hline Quantitaion & Agilent & Version 10.1 & - \\
\hline
\end{tabular}


Analysis

\section{References}

1. Stephens, L. et al. The detection, purification, structural characterization, and metabolism of diphosphoinositol pentakisphosphate(s) and bisdiphosphoinositol tetrakisphosphate(s). The Journal of biological chemistry. 268 (6), 4009-4015 (1993).

2. Menniti, F.S., Miller, R.N., Putney, J.W., JR, Shears, S.B. Turnover of inositol polyphosphate pyrophosphates in pancreatoma cells. The Journal of biological chemistry. 268 (6), 38503856 (1993).

3. Shears, S.B. Inositol pyrophosphates: Why so many phosphates? Advances in Biological Regulation. 57, 203-216 (2015).

4. Irvine, R.F., Schell, M.J. Back in the water: the return of the inositol phosphates. Nature Reviews Molecular Cell Biology. 2 (5), 327-338 (2001).

5. Szijgyarto, Z., Garedew, A., Azevedo, C., Saiardi, A. Influence of inositol pyrophosphates on cellular energy dynamics. Science. 334 (6057), 802-805 (2011).

6. Wild, R. et al. Control of eukaryotic phosphate homeostasis by inositol polyphosphate sensor domains. Science. 352 (6288), 986-990 (2016).

7. Chakraborty, A. et al. Inositol pyrophosphates inhibit Akt signaling, thereby regulating insulin sensitivity and weight gain. Cell. 143 (6), 897-910 (2010).

8. Bittner, T. et al. Photolysis of Caged Inositol Pyrophosphate InsP8 Directly Modulates Intracellular Ca2+ Oscillations and Controls C2AB Domain Localization. Journal of the American Chemical Society. 142 (24) (2020).

9. Hauke, S. et al. Photolysis of cell-permeant caged inositol pyrophosphates controls oscillations of cytosolic calcium in a $\beta$-cell line. Chemical Science. 10 (9), 2687-2692 (2019).

10. Saiardi, A., Sciambi, C., McCaffery, J.M., Wendland, B., Snyder, S.H. Inositol pyrophosphates regulate endocytic trafficking. Proceedings of the National Academy of Sciences of the United States of America. 99 (22), 14206-14211 (2002).

11. Koldobskiy, M.A. et al. p53-mediated apoptosis requires inositol hexakisphosphate kinase-2. Proceedings of the National Academy of Sciences. 107 (49), 20947 (2010).

12. Rao, F. et al. Inositol hexakisphosphate kinase-1 mediates assembly/disassembly of the CRL4-signalosome complex to regulate DNA repair and cell death. Proceedings of the National Academy of Sciences. 111 (45), 16005 (2014).

13. Williams, S.P., Gillaspy, G.E., Perera, I.Y. Biosynthesis and possible functions of inositol pyrophosphates in plants. Frontiers in Plant Science. 6, 67 (2015).

14. Wilson, M.S.C., Livermore, T.M., Saiardi, A. Inositol pyrophosphates: between signalling and metabolism. The Biochemical journal. 452 (3), 369-379 (2013).

15. Harmel, R.K. et al. Harnessing 13C-labeled myo-inositol to interrogate inositol phosphate messengers by NMR. Chemical Science. 10 (20), 5267-5274 (2019).

16. Qiu, D. et al. Analysis of inositol phosphate metabolism by capillary electrophoresis electrospray ionization mass spectrometry. Nature Communications. 11 (1), 6035 (2020).

17. Azevedo, C., Saiardi, A. Extraction and analysis of soluble inositol polyphosphates from yeast. Nature Protocols. 1 (5), 2416-2422 (2006). 
18. Wilson, M.S.C., Saiardi, A. Importance of radioactive labelling to elucidate inositol polyphosphate signalling. Phosphate Labeling and Sensing in Chemical Biology, 67-87 (2017).

19. Wilson, M.S.C., Bulley, S.J., Pisani, F., Irvine, R.F., Saiardi, A. A novel method for the purification of inositol phosphates from biological samples reveals that no phytate is present in human plasma or urine. Open biology. 5 (3), 150014 (2015).

20. Losito, O., Szijgyarto, Z., Resnick, A.C., Saiardi, A. Inositol pyrophosphates and their unique metabolic complexity: analysis by gel electrophoresis. PloS one. 4 (5), e5580 (2009).

21. Dong, J. et al. Inositol Pyrophosphate InsP8 Acts as an Intracellular Phosphate Signal in Arabidopsis. Molecular Plant. 12 (11), 1463-1473 (2019).

22. Riemer, E. et al. ITPK1 is an InsP 6 /ADP phosphotransferase that controls systemic phosphate homeostasis in Arabidopsis. bioRxiv, 2020.05.18.100297 (2020).

23. Whitfield, $\mathrm{H}$. et al. An ATP-responsive metabolic cassette comprised of inositol tris/tetrakisphosphate kinase 1 (ITPK1) and inositol pentakisphosphate 2-kinase (IPK1) buffers diphosphosphoinositol phosphate levels. The Biochemical journal. 477 (14), 26212638 (2020).

24. Ito, M. et al. Hydrophilic interaction liquid chromatography-tandem mass spectrometry for the quantitative analysis of mammalian-derived inositol poly/pyrophosphates. Journal of chromatography. A. 1573, 87-97 (2018).

25. Mantilla, B.S., Amaral, L.D.D., Jessen, H.J., Docampo, R. The Inositol Pyrophosphate Biosynthetic Pathway of Trypanosoma cruzi. ACS Chemical Biology. 16 (2), 283-292 (2021).

26. Wilson, M.S., Saiardi, A. Inositol Phosphates Purification Using Titanium Dioxide Beads. Bioprotocol. 8 (15), e2959 (2018).

27. Puschmann, R., Harmel, R.K., Fiedler, D. Scalable Chemoenzymatic Synthesis of Inositol Pyrophosphates. Biochemistry. 58 (38), 3927-3932 (2019).

28. Gu, C. et al. $\mathrm{KO}$ of 5-InsP(7) kinase activity transforms the HCT116 colon cancer cell line into a hypermetabolic, growth-inhibited phenotype. Proceedings of the National Academy of Sciences of the United States of America. 114 (45), 11968-11973 (2017).

29. Gu, C., Wilson, M.S.C., Jessen, H.J., Saiardi, A., Shears, S.B. Inositol Pyrophosphate Profiling of Two HCT116 Cell Lines Uncovers Variation in InsP8 Levels. PloS one. 11 (10), e0165286 (2016). 
Parameter

\begin{tabular}{|c|c|c|}
\hline \multirow[t]{8}{*}{$\mathrm{CE}$} & Inlet Home & Vial 1 \\
\hline & Outlet Home & Not important \\
\hline & Cassette Temperature & $25.0^{\circ} \mathrm{C}$ \\
\hline & Replenishment & Replenish Vial, Vial 1 to $1.4 \mathrm{~cm}$ \\
\hline & Precondition & Flush, 500s (Inlet Home Vial) \\
\hline & Injection & $\begin{array}{l}\text { 1. Apply pressure, } 50 \text { mbar for } 10 \mathrm{~s} \\
\text { (Injection Vial) } \\
\text { 2. Apply Pressure, } 50 \mathrm{mbar} \text { for } 5 \mathrm{~s} \text { (Inlet } \\
\text { Home Vial) }\end{array}$ \\
\hline & Timetable & $0.3 \mathrm{~min}$, Change Voltage, $30 \mathrm{kV}$ \\
\hline & Stoptime & $30 \mathrm{~min}$ \\
\hline Iso Pump & Flow & $1 \mathrm{~mL} / \mathrm{min}$ \\
\hline \multirow[t]{7}{*}{ ESI Source } & Gas Temp & $150^{\circ} \mathrm{C}$ \\
\hline & Gas Flow & $11 \mathrm{~L} / \mathrm{min}$ \\
\hline & Nebulizer & $8 \mathrm{psi}$ \\
\hline & Sheath Gas Temp & $175^{\circ} \mathrm{C}$ \\
\hline & Sheath Gas Flow & $8 \mathrm{~L} / \mathrm{min}$ \\
\hline & Capillary & 2000 V (Negative) \\
\hline & Nozzle Voltage & 2000 V (Negative) \\
\hline \multirow[t]{4}{*}{ QQQ } & Scan Type & MRM \\
\hline & Ion Funnel Parameters & Neg High Pressure RF, $70 \mathrm{~V}$ \\
\hline & & Neg Low Pressure RF, $40 \mathrm{~V}$ \\
\hline & MS Scan & MRM (see below) \\
\hline
\end{tabular}

\begin{tabular}{|c|c|c|c|c|c|c|c|}
\hline Compound Name & Precursor Ion & Product Ion & dwell & $\begin{array}{l}\text { Frag } \\
\text { (V) }\end{array}$ & $\begin{array}{l}\text { CE } \\
(V)\end{array}$ & $\begin{array}{l}\text { Cell Acc } \\
\text { (V) }\end{array}$ & Polarity \\
\hline$\left[{ }^{13} \mathrm{C}_{6}\right] \operatorname{lns} \mathrm{P}_{8}$ & 411.9 & $362.9^{a}$ & 50 & 166 & 10 & 1 & Negative \\
\hline$\left[{ }^{13} \mathrm{C}_{6}\right] \operatorname{lns} \mathrm{P}_{8}$ & 411.9 & 78.9 & 50 & 166 & 42 & 4 & Negative \\
\hline InsP 8 & 408.9 & $359.9^{a}$ & 50 & 166 & 10 & 1 & Negative \\
\hline InsP 8 & 408.9 & 78.9 & 50 & 166 & 42 & 4 & Negative \\
\hline$\left[{ }^{13} \mathrm{C}_{6}\right] \operatorname{lns} \mathrm{P}_{7}$ & 371.9 & $322.9^{a}$ & 50 & 166 & 10 & 3 & Negative \\
\hline$\left[{ }^{13} \mathrm{C}_{6}\right] \operatorname{lns} \mathrm{P}_{7}$ & 371.9 & 78.9 & 50 & 166 & 38 & 3 & Negative \\
\hline InsP7 & 368.9 & $319.9^{a}$ & 50 & 166 & 10 & 3 & Negative \\
\hline $\operatorname{lnsP}_{7}$ & 368.9 & 78.9 & 50 & 166 & 38 & 3 & Negative \\
\hline$\left[{ }^{13} \mathrm{C}_{6}\right] \operatorname{lns} \mathrm{P}_{6}$ & 331.9 & 487 & 50 & 166 & 10 & 1 & Negative \\
\hline$\left[{ }^{13} \mathrm{C}_{6}\right] \operatorname{lns} \mathrm{P}_{6}$ & 331.9 & $78.9^{a}$ & 50 & 166 & 46 & 3 & Negative \\
\hline $\operatorname{Ins}_{6}$ & 328.9 & 481 & 50 & 166 & 10 & 1 & Negative \\
\hline Ins $P_{6}$ & 328.9 & $78.9^{a}$ & 50 & 166 & 46 & 3 & Negative \\
\hline$\left[{ }^{13} \mathrm{C}_{6}\right]$ Ins $\mathrm{P}_{5}$ & 292 & $504.7^{a}$ & 50 & 166 & 10 & 1 & Negative \\
\hline$\left[{ }^{13} \mathrm{C}_{6}\right]$ Ins $\mathrm{P}_{5}$ & 292 & 78.9 & 50 & 166 & 14 & 1 & Negative \\
\hline InsP 5 & 288.9 & $498.7^{a}$ & 50 & 166 & 10 & 1 & Negative \\
\hline InsP $P_{5}$ & 288.9 & 78.9 & 50 & 166 & 14 & 1 & Negative \\
\hline $\operatorname{InsP}_{4}$ & 249 & $418.6^{a}$ & 50 & 166 & 10 & 1 & Negative \\
\hline $\mathrm{InsP}_{4}$ & 249 & 320.6 & 50 & 166 & 14 & 1 & Negative \\
\hline $\operatorname{Ins} P_{3}$ & 419 & $320.6^{a}$ & 50 & 166 & 18 & 4 & Negative \\
\hline InsP $P_{3}$ & 419 & 78.9 & 50 & 166 & 50 & 1 & Negative \\
\hline
\end{tabular}

${ }^{a} \mathrm{MRM}$ transition with the highest response for each compound (used for quantitation)

\section{Table 1}


Figure 1

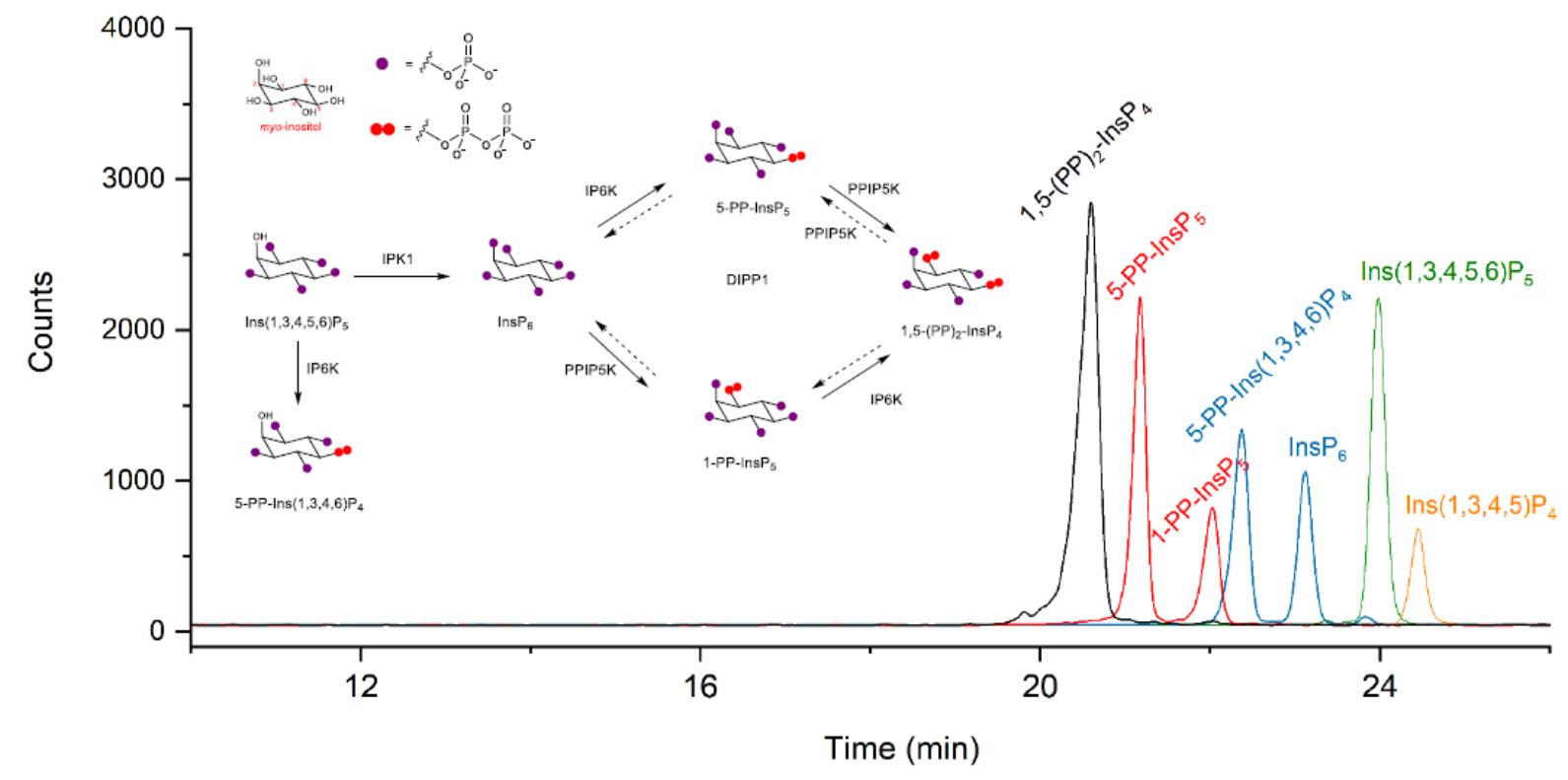

Figure 2

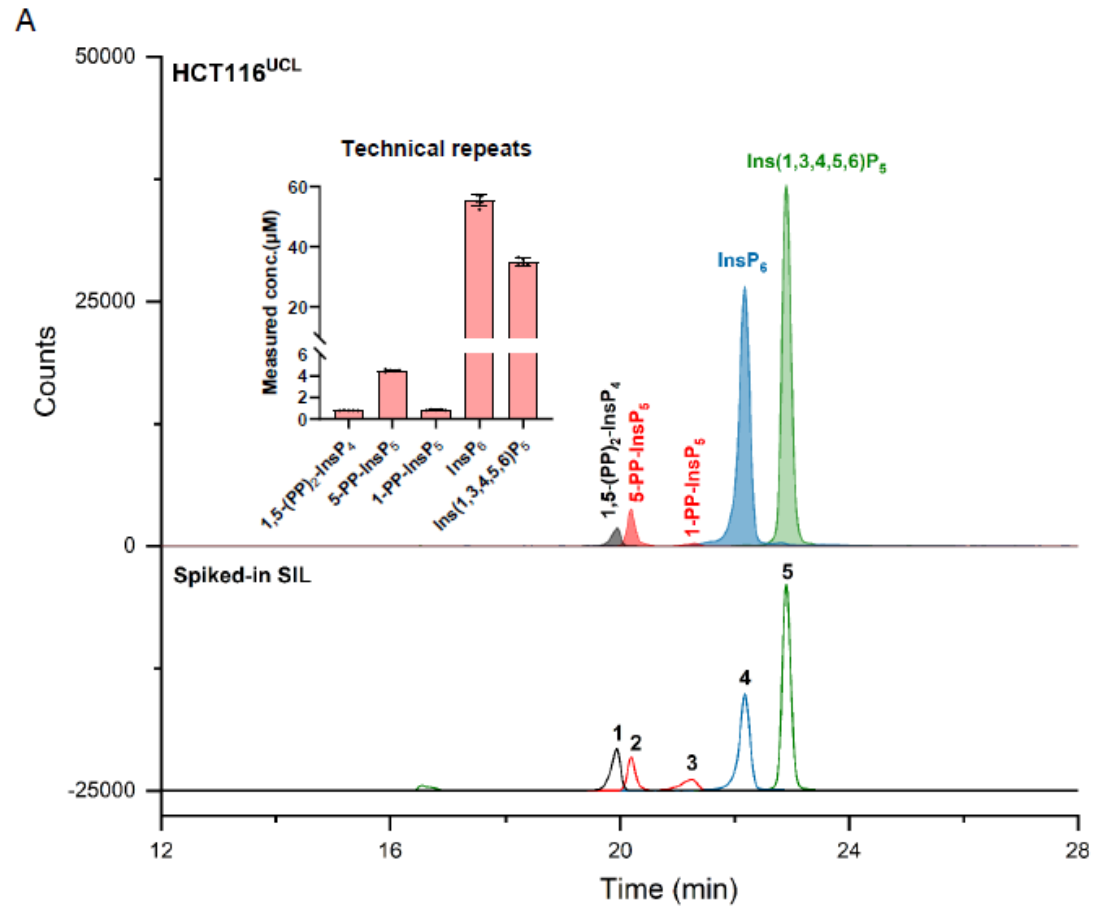

B

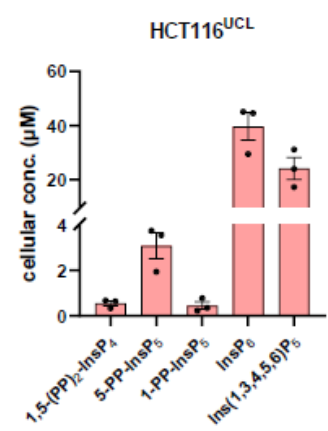

C

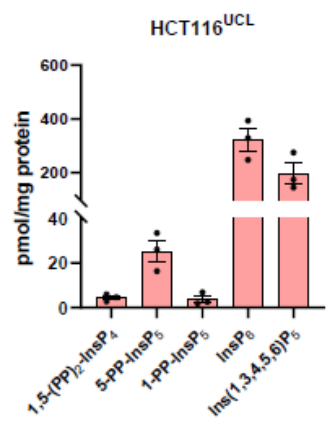




\section{Figure 3}
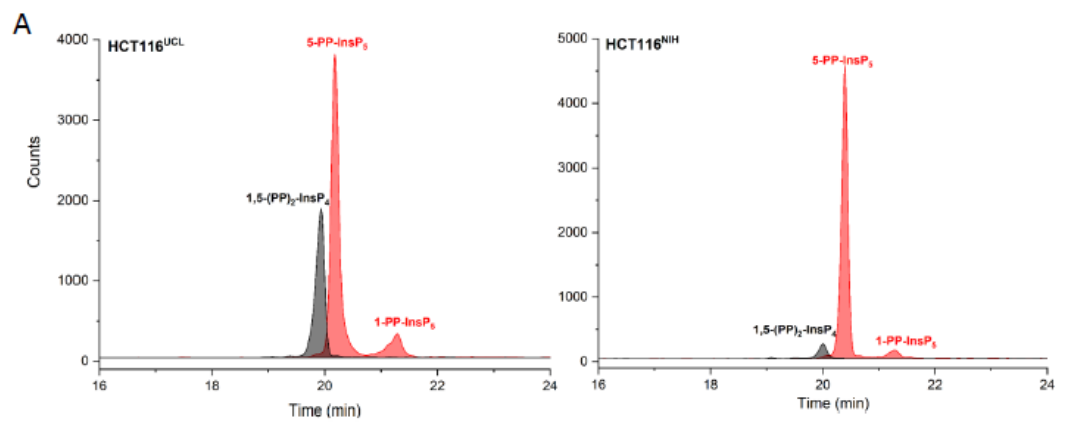

B

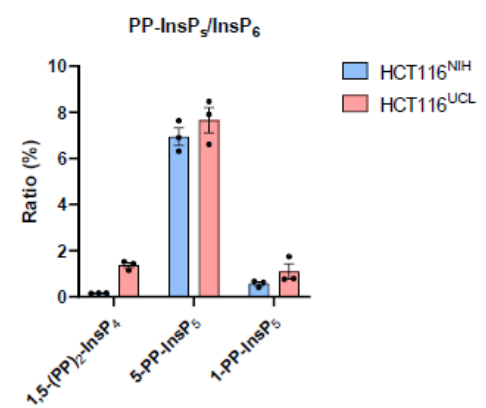

Figure 4

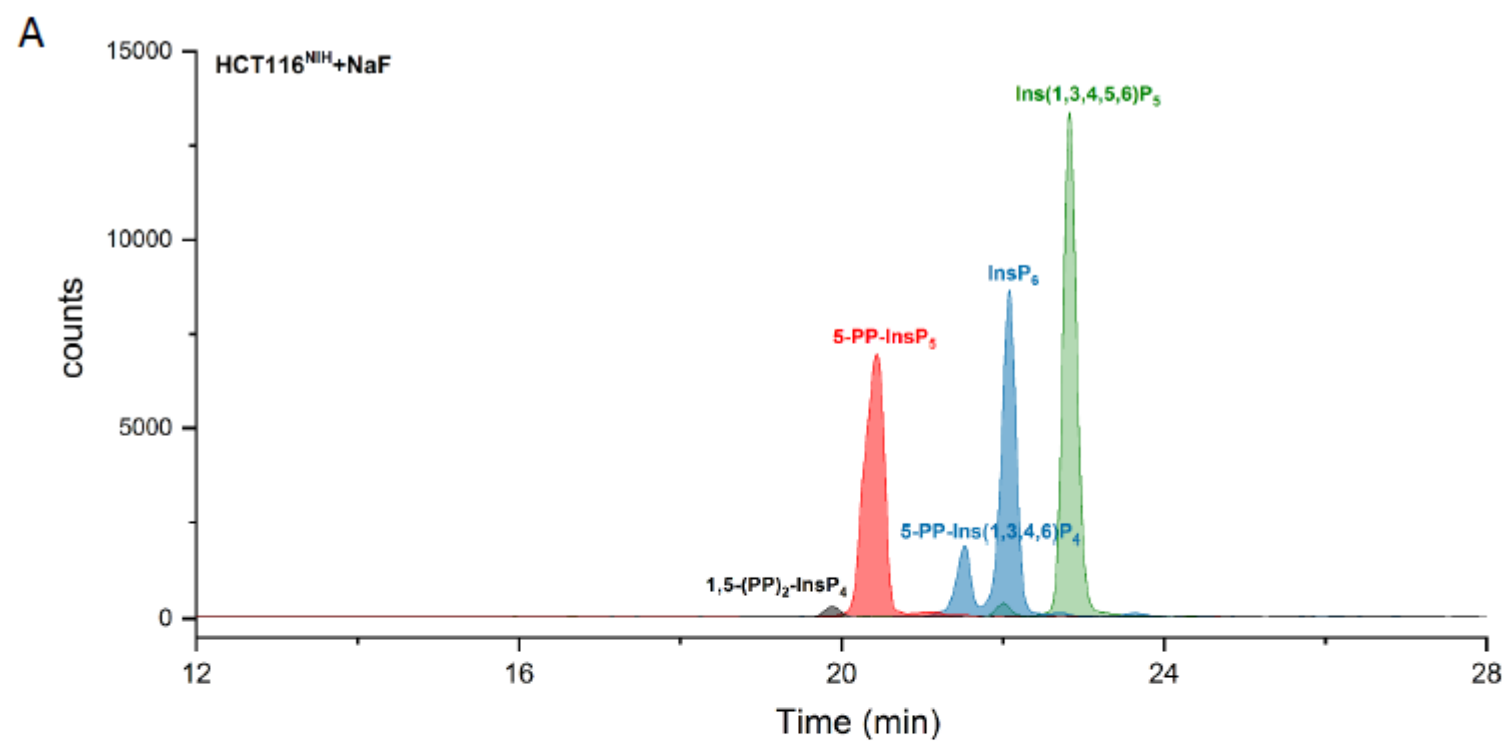

B

HCT116 NaF treatment
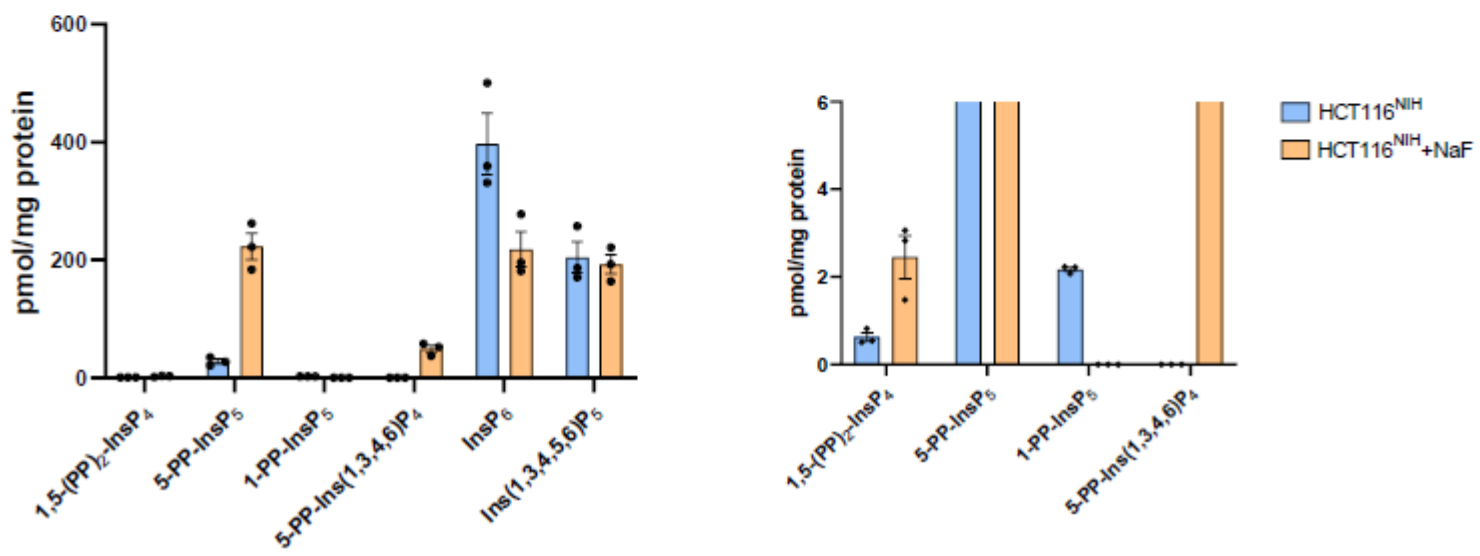